\title{
Surface Modification on Ti-6Al-4V Alloy During Corrosion in a High Temperature Ionic Liquid
}

\author{
ELENA IONELA NEACSU ${ }^{1}$, VIRGIL CONSTANTIN ${ }^{1 *}$, KAZIMIR YANUSHKEVICH ${ }^{2}$, \\ CRISTINA DONATH ${ }^{1}$, MIHAI ANASTASESCU ${ }^{1}$, ANA MARIA POPESCU ${ }^{1 *}$ \\ 1"Ilie Murgulescu" Institute of Physical Chemistry, 202 Splaiul Independentei , 060021, Bucharest, Romania \\ ${ }^{2}$ Scientific-Practical Materials Research Centre NAS, 19 P. Brovki str., Minsk, Belarus
}

\begin{abstract}
Corrosion behavior of Ti-6Al-4V alloy was investigated by anodic polarization curves in LiFNaF-KF molten salts mixture at $823 \mathrm{~K}$. The surface alloy (native composition and its modification and corrosion resistance after 4 hours immersion) was studied by XRD, SEM and XPS. XPS analysis shows $\mathrm{TiO}_{2}$ with small amount of $\mathrm{V}_{2} \mathrm{O}_{5}, \mathrm{Al}_{2} \mathrm{O}_{3}$ and $\mathrm{TiF}_{4}$, while in the electrolyte it was showed the presence of $V$ in a very low concentration. AFM demonstrates that formation of a rough and nonprotective oxide layer should be responsible for the weak protective properties of the alloy. The degradation mechanism of the alloy during corrosion is based on the formation of $\mathrm{TiF}_{4}$ and of the passing of vanadium in the molten electrolyte.
\end{abstract}

Keywords: Ti-6Al-4V, high temperature ionic liquids, corrosion, XRD, AFM, XPS

\section{Introduction}

The titanium alloys are potential materials for high temperature applications in turbine components due to their very high temperature strength and lightweight properties. Titanium and its alloys have a wide range of applications in the field's aerospace, chemical industry, marine and biomedical devices because of their combination of properties in terms of high strength to weight ratio, exceptional resistance to corrosion, and excellent biocompatibility [1-3]. Ti-6Al-4V is known as the "workhorse" of the titanium industry as this is the by far the most commonly used Ti based alloy. This is a $\alpha / \beta$ alloy which generally contain a combination of alpha $(\mathrm{Al})$ and beta $(\mathrm{V})$ stabilizers and are heat treatable to various degrees. Titanium alloy Ti-6Al-4V is the most widely used, high strength titanium alloy. Over the past 40 years, many studies have been carried out on the oxidation of titanium and titanium alloys but less attention has been paid to the high temperature oxidation. Oxygen in solution with Ti produces significant strengthening of the material. The usually excellent corrosion resistance of titanium under normal conditions is largely due to the formation of very stable, highly adherent and protective oxide films on the surface. In particular the alloy Ti-6A1-4V, due to its excellent combination of high strength, low density and high corrosion resistance, has been much studied by many researchers having in mind aeronautical and medical applications [4,5]. Although titanium based alloys exhibit good corrosion resistance due to the formation of oxide titanium on its surface, the nature, composition and thickness of the protective oxide scales depend on environmental conditions [6-8]. In a corrosive environment titanium alloys exposed to elevated temperature $(>773 \mathrm{~K}$ ) show an affinity towards oxygen in air [9] and that is why environmental degradation of $\mathrm{Ti}$ alloys at elevated temperature constitutes a major technological problem threatening to limit the exploitation of these materials. The details of high temperature corrosion behavior of Ti-6Al-4V alloy are very scanty in the literature and it is essential to understand the degradation mechanism of this alloy under high temperature corrosion conditions.

\footnotetext{
*email:virgilconstantin@yahoo.com,popescuamj@yahoo.com
} 
The aim of the present work is to investigate the surface modifications on Ti-6Al-4V alloy during corrosion in a high temperature ionic liquid (HTIL) especially as we did not found any such data in the studied literature. The native alloy and the corrosion products were analyzed by X-ray diffraction (XRD), metallographic/scanning electron microscopy (SEM), X-ray Photoelectron Spectrometry (XPS) and atomic force microscopy (AFM) techniques.

\section{Materials and methods}

\subsection{Materials and medium}

The specimen studied was Ti-6Al-4V alloy. The molten powder processing product was used to fabricate the Ti-6Al-4V alloy, by the National Institute of Research and Development for Non-Ferrous and Rare-Metals, Bucharest-Romania. The Ti-6Al-4V alloy composition determined by chemical analysis (using ASTM E2371-13) is the following: 6.0 wt.\% Al, 4.3 wt.\% V, 0.2 wt.\% Fe, 0.2 wt.\% Cr, 0.2 wt. $\%$ O, 0.02 wt. $\%$ Cu, 0.05 wt. $\%$ Si, 0.02 wt. $\%$ Ni, 0.007 wt.\% N, 0.003 wt.\% C and 89 wt.\% Ti. The Ti-6Al-4V was cut in cylindrical test pieces of $9 \mathrm{~mm}$ in diameter, $15 \mathrm{~mm}$ height. Samples were first grinded and then polished using SiC papers of different grades, including grit numbers 120, 240, $400,600,1200$. Sheets with grits of up to 600 are best-suited for polishing jobs. It should be mentioned that the grinding process was performed in one direction only. The 1200 grit surface was further polished with $0.05 \mu \mathrm{m}$ alumina paste. After the paper polishing, the next step was cloth polishing. To prevent any pollution between abrasives, the surfaces were washed with propyl alcohol. After drying this whole polishing procedure gives mirror finish to sample surfaces. Determination of corrosion rate of metals and alloys in HTIL using polarization curves is not very accurate (since the surface area of the electrode in contact with the ionic liquid may increase significantly due to corrosion. That is why we made a sheet of $\mathrm{BN}$ on the sample, in order to well delimit the working surface. The electrolyte medium for corrosion test was $(\mathrm{Li}, \mathrm{Na}, \mathrm{K}) \mathrm{F}$, all initial salts being Merck of $>99 \%$ purity. After drying, $\mathrm{LiF}, \mathrm{NaF}$ and KF, respectively a mixture of them of composition 46.5-11.5-42 mol \% (commonly referred to as FLINAK) [10] was prepared in dry box and then put into a glassy carbon crucible in a closed metallic retort. The salts mixture was further dried at $473 \mathrm{~K}$ in the reaction chamber of an electric furnace, under vacuum for $48 \mathrm{~h}$ and then the furnace was heated to $823 \mathrm{~K}$ temperature at which the corrosion test was carried out. Because KF was hygroscopic and deliquescent and certain concentration of water vapor is carried out by Ar flow, at elevated temperature; HF can be generated $\left(\mathrm{KF}+\mathrm{H}_{2} \mathrm{O} \rightarrow \mathrm{K}_{2} \mathrm{O}+2 \mathrm{HF}\right)$. Therefore, the initial molten FLINAK would contain a small amount of $\mathrm{HF}$ (in several ppm). Before each electrochemical experiment the specimens were degreased with ethanol and rinsed with deionized water and then immersed in the cell containing the electrolyte.

\subsection{Electrochemical measurements}

All electrochemical corrosion tests were performed in a closed stainless steel chamber under protection of pure Ar, by a Princeton Applied Research PARSTAT 2273 potentiostat with a specialize software "Power Corr". A conventional three electrode system was utilized, in which the quasireference electrode (RE) was a Pt sheet, the counter electrode (CE) was glassy carbon plate and working electrode (WE) was the Ti-6Al-4V alloy as described in Figure 1. Open circuit potential (OCP) and potentiodynamic polarization technique (linear and Tafel plots) were performed to evaluate the degradation mechanisms and characterize the corrosion behavior of the alloy. Each experiment was repeated at least two replicates using freshly prepared electrolyte in every time and the average of the most reliable data was taken. The samples were obtained by terminating the immersion test, and then taken out of the melt, cooled in air down to the room temperature, cleaned in distilled water and alcohol. 


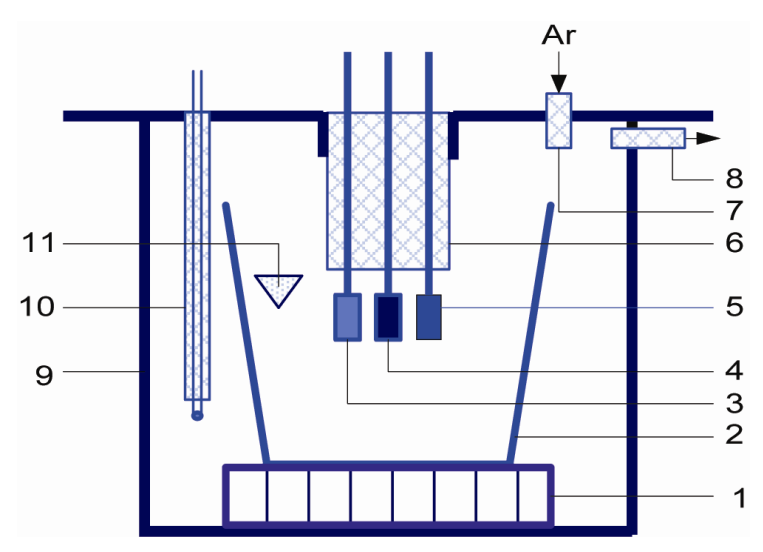

Figure 1. Experimental corrosion cell set-up:

1-ceramic support; 2-GC crucible;

3-WE; 4- CE; 5-QRE; 6-alumina sheath; 7-Ar (in);

8-vacuum (out); 9-electrical furnace;

10-thermocouple (type $S$ ); 11-molten salts

\subsection{Surface characterization}

The macro-scale compositions of the native and corroded Ti-6Al-4V alloy sample were analyzed using X-ray diffractometer (model DRON-2, Russia). Micrographs of the alloy samples before and after corrosion were made with a metallographic microscope Hund-Germany (magnification $\times 100$ 400 ) with the camera image acquisition. The morphology of the alloy after the corrosion process was analyzed by SEM analysis using an experiments "Philips XL-30-SEM", Netherland. Details about the equipment of XRD and SEM were presented in a previous work [11].

For the initial and corroded alloy samples X-ray Photoelectron Spectroscopy (XPS) surface analysis technique was carried out using a Quantera SXM equipment-Japan, with a base pressure in the analysis chamber of $10^{-9}$ Torr. The X-ray source was $\mathrm{Al} \mathrm{K}$. radiation $(1486.6 \mathrm{eV}$, monochromatized) and the overall energy resolution is estimated at $0.65 \mathrm{eV}$ by the full width at half maximum (FWHM) of the $\mathrm{Au} 4 \mathrm{f}_{7 / 2}$ line. In order to take into account, $\mathrm{C}-\mathrm{C}(\mathrm{CH})_{\mathrm{n}}$ bonding of the adsorbed hydrocarbon on the sample surface. XPS data base was used for identifying the deconvoluted peaks [12,13]. The sensitivity of the XPS method is in the range of $\left(10^{-3}-10^{-4}\right)$ of a monolayer (ppb). Quantitative analysis (relative concentrations) were estimated in the range of $\pm 10 \%$, while the accuracy for Binding Energies (B.Es) assignments was $\pm 0.2 \mathrm{eV}$.

Atomic force microscopy (AFM) measurements were carried in the non-contact mode with a XE100 apparatus from Park Systems equipped with flexure-guided, cross-talked eliminated scanners, using sharp tips ( $<8 \mathrm{~nm}$ tip radius; PPP-NCLR type from Nanosensors ${ }^{\mathrm{TM}}$ ) of app. $225 \mu \mathrm{m}$ length, 38 $\mu \mathrm{m}$ width and $48 \mathrm{~N} / \mathrm{m}$ spring constant $/ 190 \mathrm{kHz}$ resonance frequency. The topographical $2 \mathrm{D}$ and 3D AFM images were taken over the area of $10 \times 10 \mu \mathrm{m}^{2}$, and it was used the XEI program (v1.8.0)/Park Systems for displaying purpose and subsequent statistical data analysis, including the calculation of the root mean square (RMS) roughness $(\mathrm{Rq})$ and other statistic parameters. The main statistic parameters obtained for each sample are the following: $R_{p v}$ is the peak-to-valley of the image or line, or the difference between minimum and maximum; $R_{q}$ is the root-mean-squared roughness. It is the standard deviation of the height value in the image or line; $R_{a}$ is the average roughness, or the area between the roughness and its mean; $R_{s k}$ is the skewness of the selected region/line and $R_{k u}$ is the kurtosis of the selected region; $\mathrm{R}_{\mathrm{ku}}$ indicates the "spikiness" of the selected sample surface/line. 


\section{Results and discussions}

\subsection{Corrosion behavior}

The corrosion resistance of the Ti alloys is improved by the formation of thin and dense oxide films over the surfaces. The oxide films formation and stability are usually evaluated by anodic polarization tests. The corrosion tests were performed in FLINAK by the method of the time evolution of potential (OCP) and linear polarization curves as shown in figure 2. The EOCP drifts in the noble direction immediately after immersion and gradually approaches a quasi-steady state value (Ess) within $40 \mathrm{~min}$. At the time of immersion in molten LiF-NaF-KF the alloy potential was $-1.120 \mathrm{~V}$, for its stabilization to occur after about $40 \mathrm{~min}-0.946 \mathrm{~V}$. The time evolution of OCP indicates that the oxide film is thinning and consequent becomes vulnerable toward anion penetration of $\mathrm{F}^{-}$ions. Also, we noticed slight oscillations of OCP in time which may probably result from chemical interactions between fluoride ions and the structured passive film. Linear polarizations studied were carried out to estimate the polarization resistance $\left(R_{p}\right)$ for the studied alloy (Figure 2 -inside curve). The $R_{p}$ value is listed in Table 1. Tafel extrapolation to corrosion potential was obtained considering the activation control uniform corrosion of the studied sample, the existence of the well-defined Tafel region and no additional electrode reactions that would be induced by electrode potential [14] as it results from the Tafel polarization curve using "Power Corr" soft as presented in Figure 2. The corresponding corrosion parameters calculated are presented in table 1. It has to be noted that Ecorr determined from polarization curves are a little higher than those obtained from the OCP measurements. The anodic branch of the polarization curve exhibits an active-passive transition, showing a trend of weak anodic passivation of the alloy under study. The same trend was observed for the thermally oxidized Ti-6Al4V. [15] Although not shown in figure 2, current increases associated with passivity breakdown were not observed at potentials as high as $2.5 \mathrm{~V} v s$. Pt. If the penetration factor $(\mathrm{P})$ is calculated for the process of corrosion is obtained a value of $\mathrm{P}=213.75 \mathrm{~mm} / \mathrm{year}$, which corresponds to a very low stability of the alloy in the molten fluoro-chloride, well correlated with the obtained corrosion rate (CR).

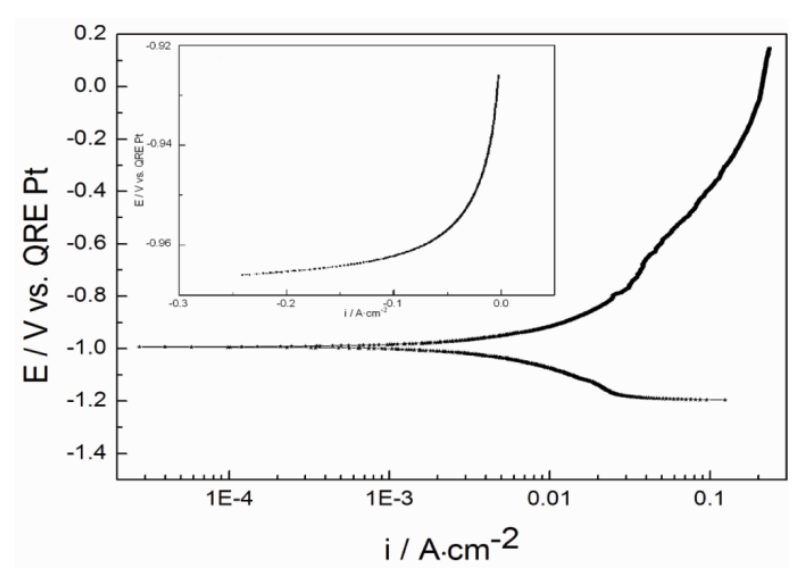

Figure 2. Potentiodynamic polarization scans (inside-linear polarization) for the corrosion of Ti-6Al-4V alloy in molten LiF-NaF-KF at $823 \mathrm{~K}, \mathrm{v}=0.166 \mathrm{mV} \cdot \mathrm{s}^{-1}$

Table 1.Electrochemical corrosion parameters potentiodynamic polarization curves

\begin{tabular}{|c|c|c|c|c|c|}
\hline Sample & $\begin{array}{c}\text { EocP } \\
(\mathbf{V})\end{array}$ & $\begin{array}{c}\mathbf{i}_{\text {cor }} \\
\left(\mathbf{A} / \mathbf{c m}^{2}\right)\end{array}$ & $\begin{array}{c}\mathbf{E}_{\mathbf{c o r}} \\
(\mathbf{V})\end{array}$ & $\begin{array}{c}\mathbf{R}_{\mathbf{p}} \\
\left(\mathbf{\Omega c m}^{2}\right)\end{array}$ & $\begin{array}{c}\text { CR } \\
(\mathbf{m m} / \mathbf{y e a r})\end{array}$ \\
\hline Ti-6Al-4V & -0.946 & $3.529 \times 10^{-3}$ & -0.993 & 2225 & 10.1 \\
\hline
\end{tabular}

*EocP=open circuit potential; $\mathrm{i}_{\text {corr }}=$ corrosion current; $\mathrm{E}_{\mathrm{corr}}=$ corrosion potential; $\mathrm{R}_{\mathrm{p}}=$ polarization rate; $\mathrm{CR}=$ corrosion rate 


\subsection{Alloy characterization and surface morphology}

The most common and widely used titanium alloy is Ti-6Al-4V, an $\alpha+\beta$ alloy, with 6 wt.\% Al stabilizing the $\alpha$ phase and $4 \mathrm{wt} . \% \mathrm{~V}$ stabilizing the $\beta$ phase $[15,16]$.

$\mathrm{X}$-ray diffraction (XRD) pattern of native Ti-6Al-4V alloy is shown in figure 3a. On initial Ti-Al-V composite X-ray diffraction pattern was not revealed any of diffraction reflexes that can confirm the presence of $\mathrm{Ti}, \mathrm{V}, \mathrm{Al}$ elements as pure metals in a composite of such composition. Therefore, the formula of the studied composite, as the X-ray diffraction experiment has shown, should contain one more element (oxygen). It is possible to write the formula of the studied composite such as Ti-Al-V-O. More correctly, the phase composition formula of the studied composite can be written as follows: (TiO) - 6(Al-O) - 4(V-O). The most probable phases with a strongly deformed crystalline unit cell, which are responsible for the diffraction reflections on the X-ray diffraction pattern in Figure 3, are given in Table 2.

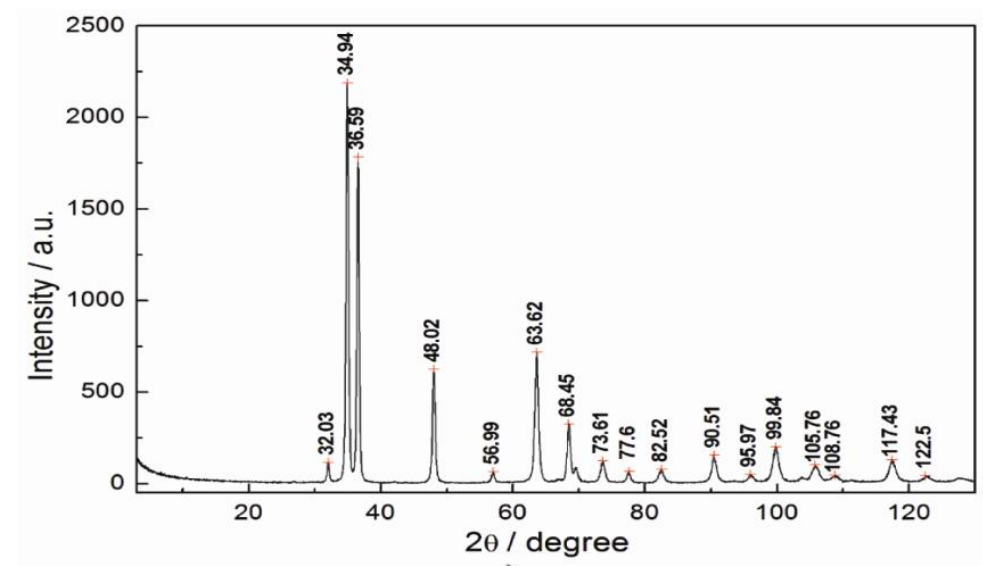

a)

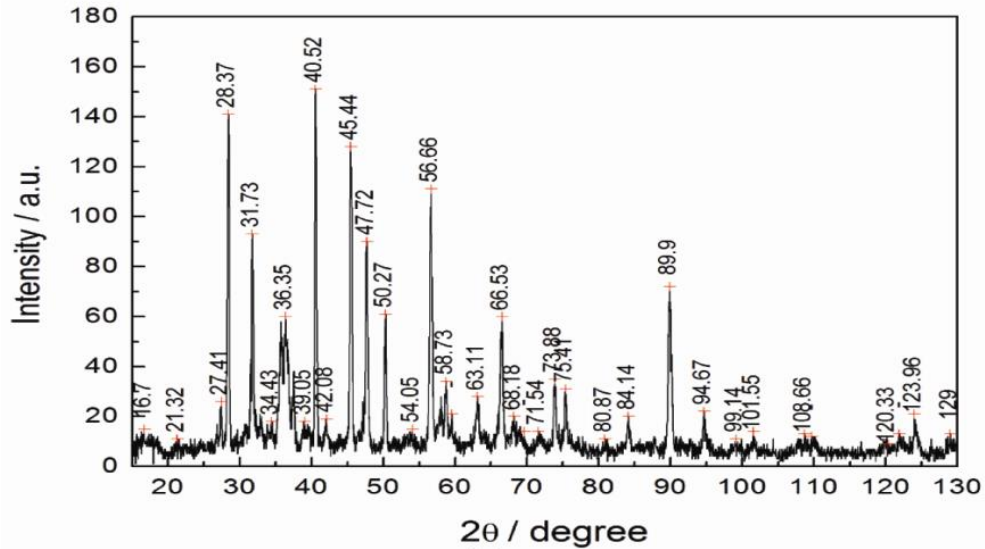

b)

Figure 3. XRD paterns of the Ti-6Al-4V alloy before (a) and after corrosion (b)

Table 2 Phase composition of the Ti-6Al-4V alloy in the initial stage [16]

\begin{tabular}{|c|c|}
\hline 20, degree & (hkl), phase composition \\
\hline 32,03 & $\begin{array}{c}(116) \mathrm{Al} \cdot \mathrm{Al}_{1.67} \mathrm{O}_{4} \text { tetragonal }(88-1609) ;(002) \mathrm{Al}_{2} \mathrm{O}_{3} \text { monoclinic }(86-1410) ;(013) \mathrm{Al}_{2} \mathrm{O}_{3} \text { orthorombic }(88- \\
1107),(88-0107) ;(211)+(203) \mathrm{V}_{2} \mathrm{O}_{5} \text { orthorombic }(85-2422)\end{array}$ \\
\hline 34,94 & $\begin{array}{l}\text { (122) } \mathrm{Al}_{2} \mathrm{O}_{3} \text { orthorombic }(88-1107) ;(002) \mathrm{Al}_{2} \mathrm{O}_{3} \text { monoclinic }(86-1410) ;(117) \mathrm{Al}^{-} \mathrm{Al}_{1.67} \mathrm{O}_{4} \text { tetragonal } \\
(88-1609) ;(110) \mathrm{Ti}_{2} \mathrm{O}_{3} \text { rhombohedral }(71-1046),(89-4746) ;(224)+(015) \mathrm{Ti}_{6} \mathrm{O}_{11} \text { triclinic }(76-1266) ;\end{array}$ \\
\hline 36.59 & $\begin{array}{c}\text { (111) } \mathrm{Al}_{2} \mathrm{O}_{3} \text { monoclinic }(86-1410) ;(113) \mathrm{Al}_{2} \mathrm{O}_{3} \text { orthorombic }(88-1107) ;(113) \mathrm{Ti}_{3} \mathrm{O}_{5} \text { monoclinic }(27- \\
\text { 0905); (110) } \mathrm{V}_{2} \mathrm{O}_{3} \text { rhombohedral }(84-0317) ;(033)+(024) \mathrm{Ti}_{6} \mathrm{O}_{11} \text { triclinic }(76-1266) ;(013)+(104) \mathrm{V}_{2} \mathrm{O}_{5} \\
\text { orthorombic }(85-2422)\end{array}$ \\
\hline 48.02 & $\begin{array}{c}(300)+(301)+\left(\begin{array}{lll}1 & 0 & 12\end{array}\right) \mathrm{Al} \cdot \mathrm{Al}_{1.67} \mathrm{O}_{4} \text { tetragonal }(88-1609) ;(222)+(042)+(203) \mathrm{Al}_{2} \mathrm{O}_{3} \text { orthorombic }(88- \\
0107) ;(214) \mathrm{V}_{2} \mathrm{O}_{5} \text { orthorombic }(85-2422)\end{array}$ \\
\hline 63,62 & 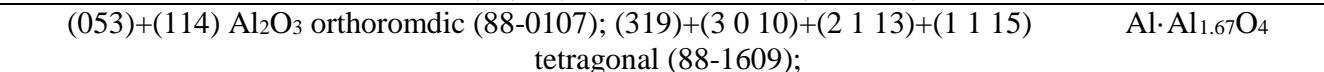 \\
\hline
\end{tabular}


When comparing the X-ray patterns of the initial Ti-6Al-4V alloy (see figure 3a) with the corroded one at high temperature $823 \mathrm{~K}$ using the corrosive environment of LiF-NaF-KF melt, time of corrosive action $\mathrm{t}=240 \mathrm{~min}$ (figure $3 \mathrm{~b}$ ), one can see that after corrosive processes on X-ray patterns significantly increases the number of diffraction reflections. This fact greatly complicates the decoding and precise definition of the formed new phases. Analysis of the X-ray diffraction pattern in figure $3 \mathrm{~b}$ shows that after the action of corrosive processes were formed oxides of new compositions in the (Ti-O) - (Al-O) - (V-O) composite. There was occurred a redistribution of oxygen content in the newly formed oxygen-containing phases with strongly deformed crystal cell $[18,19]$. As a result of this effect, the intensity of the diffraction reflections of all oxide phases presented in the investigated composite strongly decreased. On the obtained XRD the angle reflexes are shifted by $\sim 15-20 \%$ and redistribution of intensities occurs, so there is reason to assume that crystal cell is deformed. The X-ray diffraction pattern of Ti-6Al-4V corroded alloy reveals the shift of peaks pertaining to $\alpha$-Ti to lower diffraction angles, suggesting an increase in lattice parameters. Broadening of the $\alpha$-Ti peaks and appearance of a shoulder pattern at lower diffraction angles (between 34.43-39.05 degree) confirms the presence of oxygen diffusion layers. The most probable new phases of oxides with a highly deformed crystalline unit cell have a more complex formulary composition of oxide phases, which differs from the initial composite. Table 3 lists the most probable oxides of titanium, aluminum, and vanadium, which are responsible for the diffraction reflections on the X-ray diffraction pattern in figure $3 \mathrm{~b}$.

Table 3 Phase composition of the Ti-6Al-4V alloy in the corroded state [16]

\begin{tabular}{|c|c|}
\hline 20, degree & (hkl), phase composition \\
\hline 27.01 & $(1110) \mathrm{V}_{7} \mathrm{O}_{13}$ triclinic $(71-0041)$ \\
\hline 27,41 & $\begin{array}{c}\text { (110) } \mathrm{Ti}_{0.928} \mathrm{O}_{3} \text { tetragonal }(89-0552) ;(110) \mathrm{Ti}_{0.936} \mathrm{O}_{2} \text { tetragonal }(89-0554) ;(110) \mathrm{TiO}_{1.95} \text { tetragonal }(73- \\
1782) ;(013)+(104) \mathrm{V}_{2} \mathrm{O}_{5} \text { orthorombic }(85-2422)(211)+(121) \mathrm{Ti}_{6} \mathrm{O}_{11} \text { triclinic }(76-1266) ; \\
(125)+(029) \mathrm{V}_{7} \mathrm{O}_{13} \text { triclinic }(71-0041) ;\end{array}$ \\
\hline 28,37 & $\begin{array}{c}\text { (121) } \mathrm{Ti}_{8} \mathrm{O}_{15} \text { triclinic }(85-1060) ;(127)+(018) \mathrm{V}_{7} \mathrm{O}_{13} \text { triclinic }(71-0041) ;(103)+(230) \mathrm{Ti}_{6} \mathrm{O}_{11} \text { triclinic } \\
(76-1266) ;\end{array}$ \\
\hline 31.73 & $\begin{array}{c}(127)+(114) \mathrm{Ti}_{8} \mathrm{O}_{15} \text { triclinic }(85-1060) ;(401) \mathrm{Al}_{2} \mathrm{O}_{3} \text { monoclinic }(23-1009) ;(113) \mathrm{Ti}_{3} \mathrm{O}_{5} \text { monoclinic }(27- \\
0905) ;(110) \mathrm{V}_{2} \mathrm{O}_{3} \text { rhombohedral (84-0317); (222)+(130) } \mathrm{Ti}_{6} \mathrm{O}_{11} \text { triclinic }(76-1266) ;(013)+(104) \mathrm{V}_{2} \mathrm{O}_{5} \\
\text { orthorombic }(85-2422)\end{array}$ \\
\hline 36.05 & (101) $\mathrm{TiO}_{1.95}$ tetragonal (73-1782); (110) $\mathrm{Ti}_{0.936} \mathrm{O}_{2}$ tetragonal (89-0554); \\
\hline 36.35 & $(111) \mathrm{Al}_{2} \mathrm{O}_{3}$ monoclinic $(09-0440)$ \\
\hline 40.52 & $(2018)+(2 \quad 115)$ Ti8 $\mathrm{O}_{15}$ triclinic $(85-1060) ;(026)+(216) \mathrm{V}_{7} \mathrm{O}_{13}$ triclinic $(71-0041)$ \\
\hline 45,44 & $\begin{array}{c}(053)+(114) \mathrm{Al}_{2} \mathrm{O}_{3} \text { orthoromdic }(88-0107) ;\left(\begin{array}{lll}319\end{array}\right)+\left(\begin{array}{lll}3 & 0 & 10\end{array}\right)+\left(\begin{array}{lll}2 & 1 & 13\end{array}\right)+\left(\begin{array}{lll}1 & 1 & 15\end{array}\right) \mathrm{Al} \cdot \mathrm{Al}_{1.67^{\circ}} 4 \text { tetragonal }(88- \\
1609)\end{array}$ \\
\hline 47.72 & $(600) \mathrm{Al}_{2} \mathrm{O}_{3}$ monoclinic $(23-1009) ;(006) \mathrm{Al}_{2} \mathrm{O}_{3}$ monoclinic $(09-0440)$ \\
\hline 50.27 & $(015) \mathrm{Al}_{2} \mathrm{O}_{3}$ monoclinic $(09-0440)$ \\
\hline 54.05 & (210) $\mathrm{TiO}_{1.95}$ tetragonal $(73-1782) ;(211) \mathrm{Ti}_{0.936} \mathrm{O}_{2}$ tetragonal (89-0554); \\
\hline 56.66 & $\begin{array}{l}\text { (139) } \mathrm{TiO}_{1.95} \text { tetragonal }(73-1782) ;(220) \mathrm{Ti}_{0.936} \mathrm{O}_{2} \text { tetragonal }(89-0554) ; \\
\text { (115) } \mathrm{Al}_{2} \mathrm{O}_{3} \text { monoclinic }(09-0440) ;(133)+(430) \text { triclinic } \mathrm{V}_{5} \mathrm{O}_{9}(85-1514)\end{array}$ \\
\hline 66,53 & $\begin{array}{c}(151)+(410)+(224)+(452) \text { triclinic } \mathrm{V}_{5} \mathrm{O}_{9}(85-1514) ;(120) \mathrm{Al}_{2} \mathrm{O}_{3} \text { monoclinic }(09-0440) \\
(144)+(325)+(125)+322)+(243) \text { triclinic } \mathrm{Ti}_{5} \mathrm{O}_{9}(76-1690)\end{array}$ \\
\hline 89.9 & $\begin{array}{l}\text { (222) } \mathrm{Ti}_{0.936} \mathrm{O}_{2} \text { tetragonal }(89-0554) ;(222) \mathrm{TiO}_{1.95} \text { tetragonal }(73-1782) ;(227) \mathrm{V}_{2} \mathrm{O}_{5} \text { orthorombic }(85- \\
2422)\end{array}$ \\
\hline
\end{tabular}

From the images of Ti-6Al-4V alloy embedded in the BN before and after the high temperature corrosion process (Figure $4 \mathrm{a}, \mathrm{b}$ ) we can see exactly what caused the corrosion of the surface changes (around $1 \mathrm{~mm}$ alloy since at the beginning of the experiment the alloy was at the same level as $\mathrm{BN}$ ) and one can observed some traces of electrolyte oxides on the sample. Regarding the corrosive electrolyte, if at the beginning of the experiment this was clear at the end of the corrosion process after cooling it presents some slightly yellowish gray portion which represent metal deposits (probably from the component passed into electrolyte during corrosion and we will see what it is after the XPS analysis of the electrolyte). It is very clearly that the corrosion process produced some crevices on the surface of the alloy. 


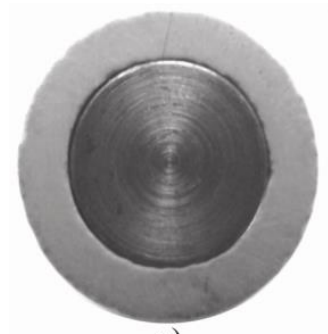

a)

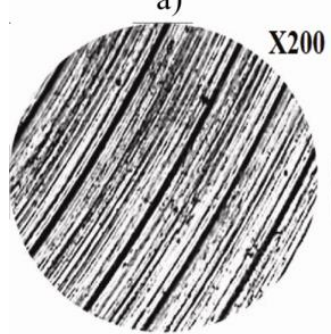

c)

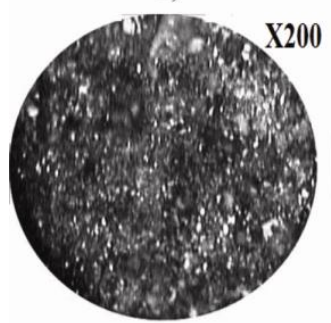

e)

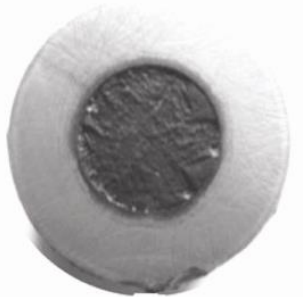

b)

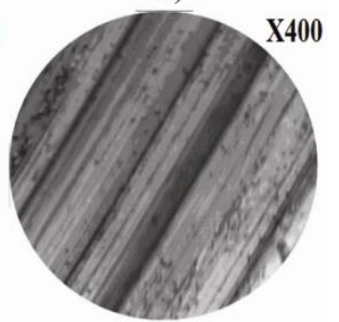

d)

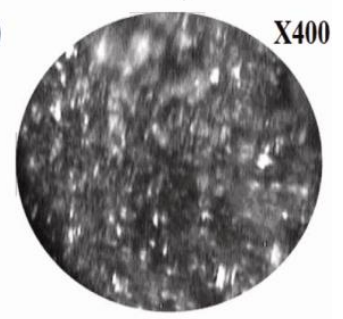

f)
Figure 4. Metallographic micrographic images of the Ti-6Al-4V sample before and after corrosion: embedded in the boron nitride sheath $(a, b)$; initial stage $(\mathrm{c}, \mathrm{d})$; corroded $(e, f)$

Metallographic microscopy examinations of the alloy specimen (Figure 4c, d) revealed a specific lamellar microstructure with striations and cracks where oxygen or fluorine ions can easily penetrate and further degrading the alloy. After corrosion (Figure $4 \mathrm{e}, \mathrm{f}$ ) the image of the alloy surface has a completely different look with a multitude of grains which are oxide grains. Those data are in good agreement with the surface morphology of the corroded alloy analyzed by SEM (Figure 5), which discovered in the matrix-scale of the alloy large pits and even cavitations erosion, implying the poor adhesive ability of the passive oxide film (well correlated with Figure $4 b$ ).

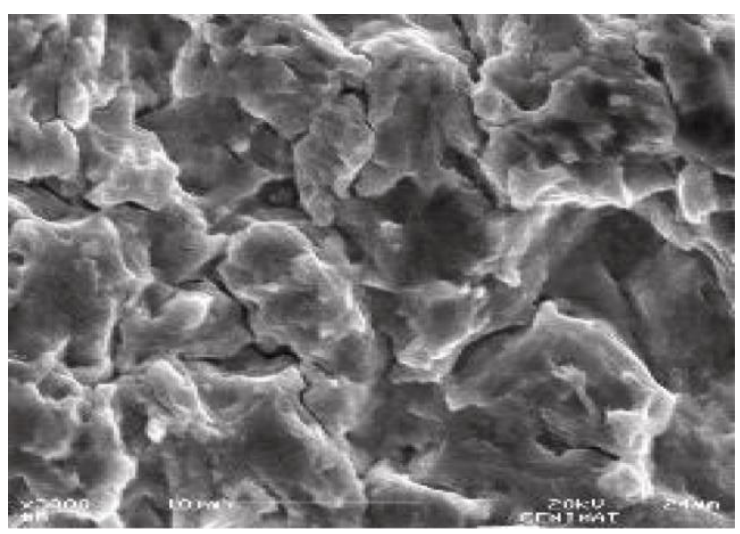

Figure 5. SEM micrograph show surface morphology of the Ti-6Al-4V sample after the corrosion with the cavitations erosion present

When being exposed to air metals and alloys are subject of oxidation. To be able to protect the underlying metal, the oxide has to meet some requirements such as good adhesion to the metal, a good crack healing ability, high thermodynamic stability in the working environment and low vapor pressure of the oxide [20]. $\mathrm{Al}_{2} \mathrm{O}_{3}$ is one of the oxides that fulfill these requirements best. The surface oxides on some alloys containing aluminium consist only of $\mathrm{Al}_{2} \mathrm{O}_{3}$. However, in the case of titanium alloys, the $\mathrm{TiO}_{2}$ is equally stable and thus inhibits the growth of aluminium oxide, wherefore the oxide consists of both titanium and aluminium [20]. In surface oxides on Ti-6Al-4V formed naturally in air, 
the aluminium has been detected as $\mathrm{Al}_{2} \mathrm{O}_{3}$ and is enriched at the surface [21]. Vanadium cannot be detected at the outermost surface in natural oxides; it is located below the top surface and may only be observed after some sputtering either by XPS or AES [22, 23].

For the characterization of the surface of Ti-6Al-4V native alloy the specimen was examined by XPS. The XPS probe spectrum of the alloy studied after $\sim 0.1 \mathrm{~min}$ sputtering (Figure 6 , below the spectrum) showed strong Ti, O, mean signals for Al, V and less intensive peaks for Ar, C. After $\sim 0,2$ min of sputtering, all the signals, except those from Ti, Al, V and $\mathrm{O}$, disappeared, indicating that the other elements were contaminated on the surface, while after 1 minute the scanning spectra are sprayed and discloses the presence of Ti, Al, V alloying elements in elemental form Ti0, Al0 and V0.

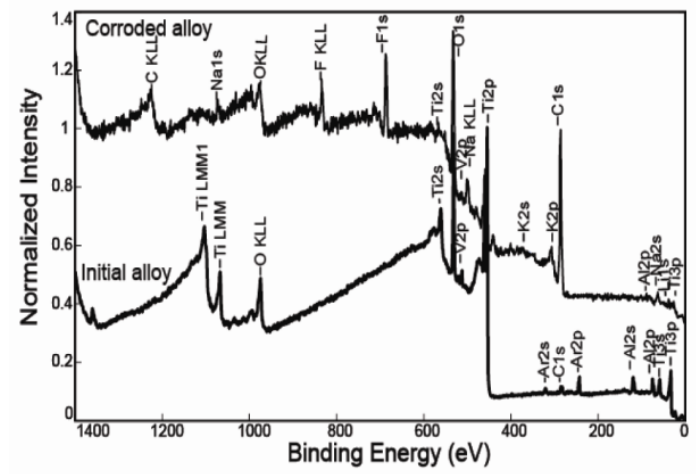

Figure 6. XPS survey spectra for the Ti-6Al-4V alloy: before and after corrosion

The XPS spectra deconvolved for Ti2p, A12p and V2P at the beginning of the XPS analysis show the surface of the alloy which mainly revealed $\mathrm{TiO} 2$ with small amounts of $\mathrm{Al} 2 \mathrm{O} 3$, after metallic $\mathrm{Ti}$, $\mathrm{Al}$ and $\mathrm{V}$ were detected. We can assume that when the sample was sprayed, the very thin (nm) oxide layer was destroyed. Thus, Ar + sputtering can change the chemical states (reducing the ions) and the composition of the ions from the surface of the material. The corresponding binding energies (B.E.) for titanium, aluminum and vanadium in the natural Ti-6Al-4V alloy are shown in Table 4.

To characterize the oxide films formed on the surface of Ti-6Al-4V alloy, the corroded sample was cleaned in ethanol and then examined by XPS analysis. Figure 6 (upper spectrum) shows the scan spectra for the Ti-6Al-4V alloy after the corrosion process, which confirms the presence of $\mathrm{Na}, \mathrm{K}, \mathrm{Li}$, $\mathrm{F}$ (from electrolyte) and Ti, Al, V (alloy elements) as well as $\mathrm{C}$ and $\mathrm{O}$. This behavior is generated by the fact that the electrolyte layer deposited on the surface of the electrode (sample alloy) is not thick enough and sufficiently adherent and was difficult to completely split. After the aggressive cleaning of the analytical space, high resolution spectra correspond to the main elements of the alloy.

Table 4. The binding energies for the formed compounds in Ti-6Al-4V alloy, calculated from XPS spectra

\begin{tabular}{|l|l|l|}
\hline Ti-6Al-4V alloy & $\begin{array}{l}\text { B.E. } \\
(\mathbf{e V})\end{array}$ & $\begin{array}{l}\Delta \text { B.E. } \\
(\mathbf{e V})\end{array}$ \\
\hline Before corrosion & $453.9 ; 460.0$ & 6,1 \\
\hline $\mathrm{Ti}_{2} \mathrm{p}_{3 / 2}, \mathrm{Ti}_{2} \mathrm{p}_{1 / 2}$ & 71.7 & - \\
\hline $\mathrm{Al} 2 \mathrm{p}$ & $512.2 ; 519.7$ & 7,5 \\
\hline $\mathrm{V}_{2} \mathrm{p}_{3 / 2}, \mathrm{~V} 2_{1 / 2}$ & \multicolumn{2}{|l|}{} \\
\hline After corrosion & $459.0 ; 465.2$ & 6,2 \\
\hline $\mathrm{TiF}_{4} / \mathrm{TiO}_{2} 2 \mathrm{p}_{3 / 2}, 2 \mathrm{p}_{1 / 2}$ & $457.9 ; 463.5$ & 5,6 \\
\hline $\mathrm{Ti}_{1} \mathrm{suboxides}^{\mid}$ & - \\
\hline $\mathrm{Al}_{2} \mathrm{O}_{3}$ & 74.0 & - \\
\hline $\mathrm{AlF}_{3}$ & 75.0 & - \\
\hline $\mathrm{V}_{2} \mathrm{O}_{5}$ & 518.5 & - \\
\hline $\mathrm{Na}_{3} \mathrm{VO}_{4} / \mathrm{NaVO}_{3} / \mathrm{MVF}_{6}$ & 517.5 & \\
\hline
\end{tabular}


Figure 7 show the deconvoluted spectra for the Ti2p, A12p, V2p, O1s, and F1s. The deconvoluted spectrum of Ti2p (Figure 7a) shows the existence of $\mathrm{Ti}^{4+}$ and $\mathrm{Ti}^{3+}$ and the presence of two peaks at $459.2 \mathrm{eV}$ and $464.8 \mathrm{eV}$, which correspond to a mixture of compounds $\left(\mathrm{TiO}_{2}, \mathrm{TiF}_{4}\right)$ and two little peaks at $456.8 \mathrm{eV}$ and $462.4 \mathrm{eV}$ corresponding to suboxides of titanium. [24,25] The main transition for aluminum namely Al2p indicates after deconvolution (Figure $7 \mathrm{~b}$ ) two big peak corresponding to formation of oxide $\mathrm{Al}_{2} \mathrm{O}_{3}$ at a binding energy of $73.9 \mathrm{eV}$ and a little peak corresponding to the presence of $\mathrm{AlF}_{3}$ with chemical binding energy of $74.7 / 75.8 \mathrm{eV}$. Also vanadium (Figure 7c) is contained in both the oxided $\mathrm{V}^{5+} ; \mathrm{V}^{3+}$, as well in the form of $\mathrm{Na}_{3} \mathrm{VO}_{4} / \mathrm{NaVO}_{3} / \mathrm{MVF}_{6}$. The two observed peaks on the spectrum are located at 581.0-518.5 eV corresponding to $\mathrm{V}_{2} \mathrm{O}_{5}$ and respectively at 517.3517.5 for $\mathrm{Na}_{3} \mathrm{VO}_{4} / \mathrm{NaVO}_{3} / \mathrm{MVF}_{6}$ [26,27]. All of the above peaks for Ti, $\mathrm{Al}$ and $\mathrm{V}$ shown above can be attributed to the formation of compounds in the film formed on the corroded alloy. This means that the passive film formed on the corroded Ti-6Al-4V alloy consists of a mixture of oxides and fluorides. Figure $7 \mathrm{~d}$ shows the deconvoluted oxygen spectrum. The presence of the $\mathrm{O} 1$ spectrum consisted of two peaks: a high primary peak located at $530.71 \mathrm{eV}$ is attributed to the presence of metal oxide type oxygen on the surface of the alloy and a minor peak located at $532.22 \mathrm{eV}$ corresponding to the $\mathrm{OH}$ oxygen. [24] Regarding the F1s spectrum (Figure 7 e), its presence confirms the formation of fluorides, as shown in Figure 7a-c. The values of binding energies (B.E.) XPS corresponding to the calculated data are presented in table 4. As the corrosion time increases, the thickness of the oxide containing $\mathrm{Al} 2 \mathrm{O} 3$ and $\mathrm{TiO} 2$ increases. Since the intensity of $\mathrm{V} 2 \mathrm{p}$ and $\mathrm{Al} 2 \mathrm{p}$ (from XPS analysis) is much lower than that of Ti2p (as shown in Figure 7), this indicates that the main component of the passive film is $\mathrm{TiO} 2$
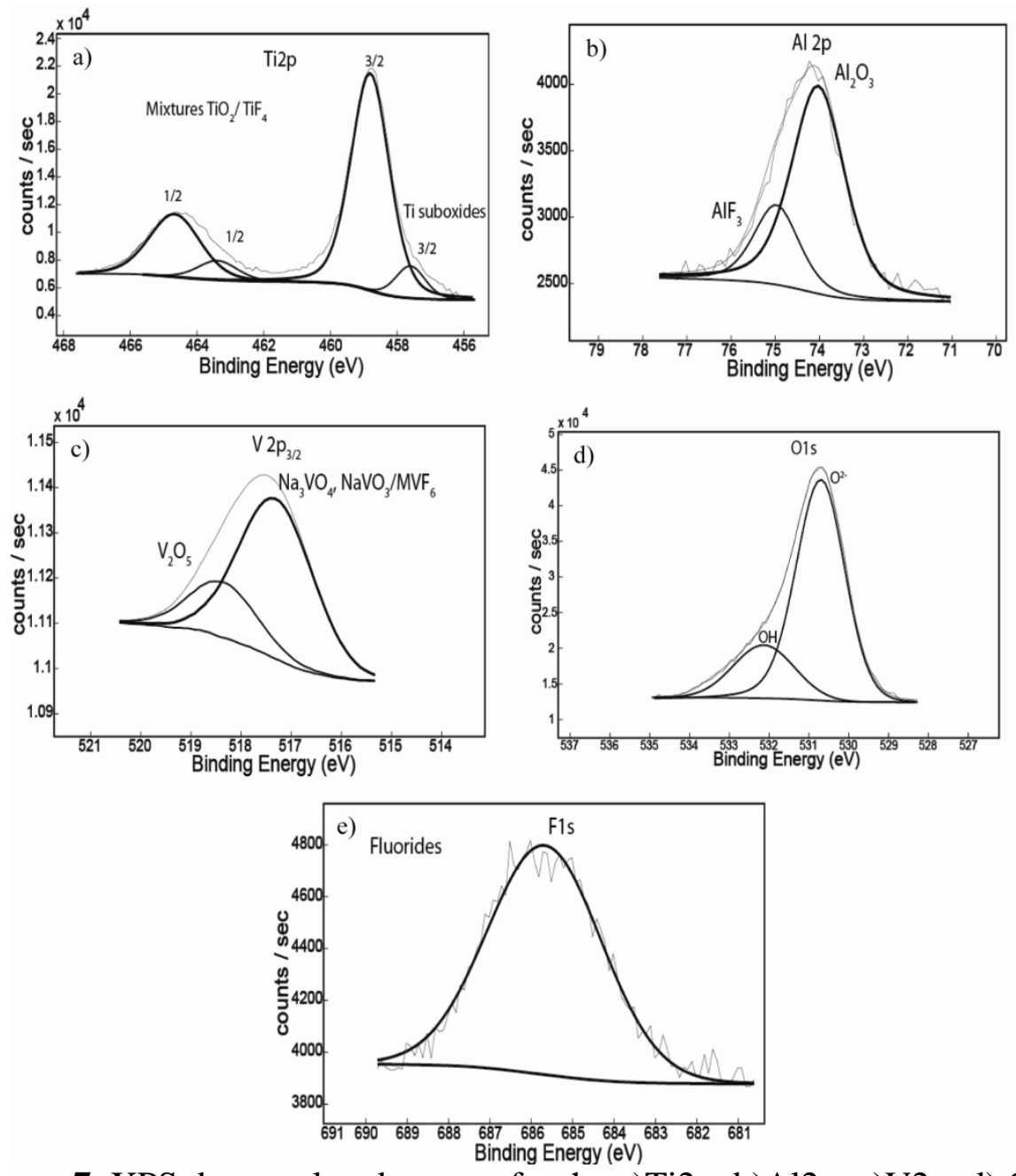

Figure 7. XPS deconvoluted spectra for the a)Ti2p, b)Al2p, c)V2p, d) O1s, e) F1s obtained from the analysis of the corroded Ti-6Al-4V alloy. 
As for the analysis of the electrolyte after the corrosion process (Figure 8) the XPS evidences the existence of vanadium in very low concentrations (almost below the detection limit of the analysis), so what we saw in the electrolyte after the corrosion process was in fact vanadium. The scan survey XPS spectrum of the electrolyte after corrosion (figure 8a) shows the presence of the peaks corresponding to: Na, K, Li, V, F, O, C. The deconvoluted spectrum for V2p (Figure 8b) show the presence of vanadium in the elemental form $\left(\mathrm{V}^{0}\right)$ in the electrolyte.
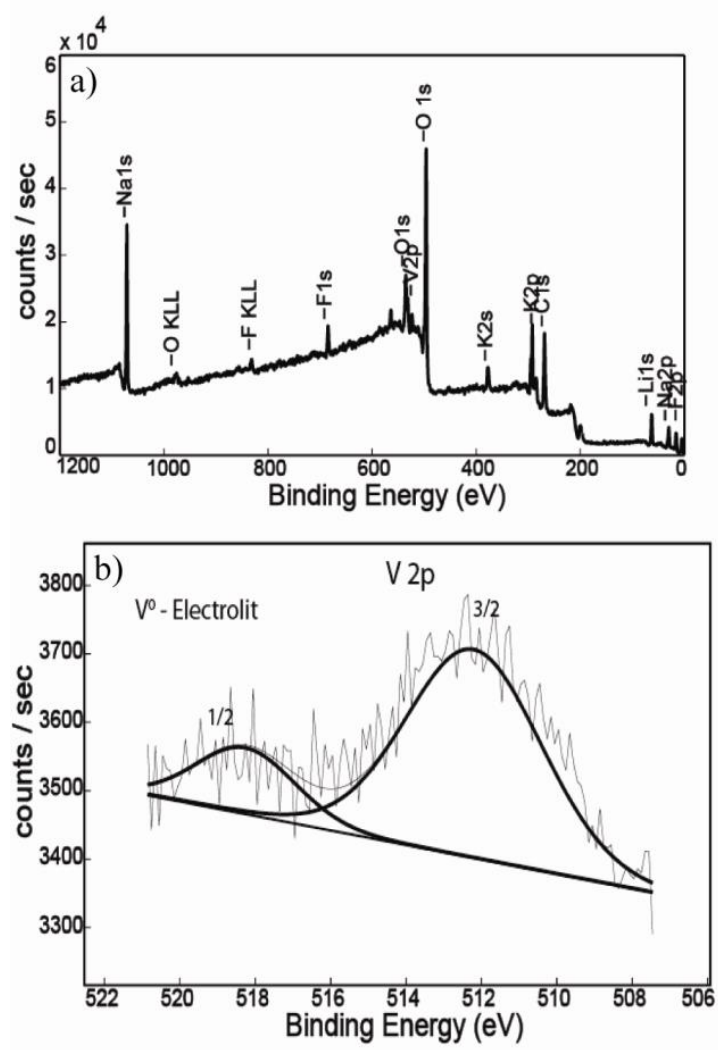

Figure 8. XPS analysis of the LiF-NaF$\mathrm{KF}$ electrolyte after the corrosion of Ti$6 \mathrm{Al}-4 \mathrm{~V}$ alloy in it at $823 \mathrm{~K}$ : (a) the survey spectrum; (b) the deconvoluted spectrum for V2p.

Finally after the XPS study, we can conclude that in the Ti-6Al-4V alloy corroded in molten salt LiF-NaF-KF at $823 \mathrm{~K}$, the predominant form is $\mathrm{TiO}_{2}$, with small amounts of $\mathrm{Al}_{2} \mathrm{O}_{3}$ and $\mathrm{V}_{2} \mathrm{O}_{5}$. The tendency to form oxides is as follows, according to the free energies of formation: $\mathrm{TiO}_{2}, \mathrm{Al}_{2} \mathrm{O}_{3}$ and $\mathrm{V}_{2} \mathrm{O}_{5}$ [28-30]. So we can conclude that during corrosion of the alloy Ti-6Al-4V at high temperature in molten fluoride mixture an oxide film is formed with the mainly composition of $\mathrm{TiO}_{2}$. The degradation mechanism of the alloy during corrosion is based on the formation of $\mathrm{TiF}_{4}$ and of the passing of vanadium in the molten electrolyte. Atomic force microscopy (AFM) complete the study on high temperature corrosion of Ti-6Al-4V alloy in the HTIL used (LiF-NaF-KF). Thus, figure 9a shows the 2D AFM images (at the scale of $10 \times 10 \mu \mathrm{m}^{2}$ ) presented in the "enhanced color" view mode together with the corresponding surface profile (line scan) fro the bare Ti-6Al-4V samples (reference surface). The roughness of the reference substrate could be evaluated from the vertical amplitude of line scan presented near the AFM image, of the order of tens of nm. On the surface of the bare substrate some trenches are visible which are most probably due to mechanical polishing of the electrode substrate. A $3 \mathrm{D}$ view of the reference Ti-Al-V is shown below, in Figure 9c. After corrosion (Figure 9b and d) the morphology of the Ti-6Al-4V sample is completely changed, as appear to be covered mostly with faceted crystallites from the molten salts solution. The crystallites have dimensions on micrometric scale and seem to be preferentially crystallized in a cubic system. On the corresponding surface profile (line scan) near figure $8 \mathrm{~b}$ it could be observed as the crystallites on the Ti-Al-V surface are one order of magnitude rougher than the reference substrate. AFM images before and after the corrosion process illustrates very clearly the influence of corrosion on the alloy surface, not only by changing the shape but also give rise to roughness. The surface is not homogenous corroded and presents some cavity 
corrosion. The main statistic parameters obtained for each sample before and after corrosion are listed in table 5 and demonstrate the corrosion process.
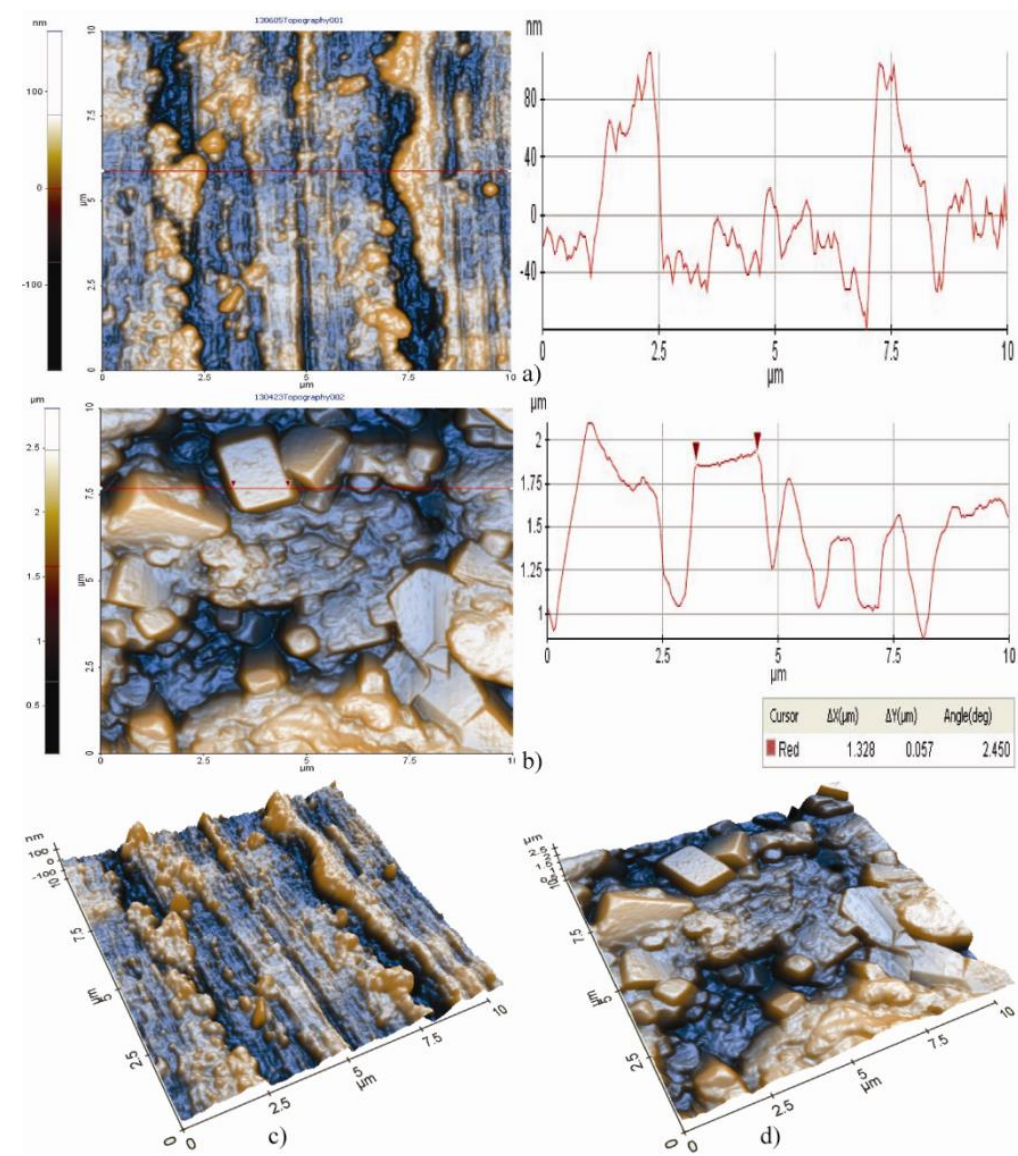

Figure 9. 2D and 3D: enhanced color \& line profile topographic AFM images for the Ti-6Al-4V sample in the initial $(a, c)$ and corroded stage $(b, d)$

Table 5 The calculation of the root mean square ( $\mathrm{rms})$ roughness $\left(\mathrm{r}_{\mathrm{q}}\right)$ and other statistic parameters from the AFM images for the Ti-6Al-4V alloy

\begin{tabular}{|c|c|c|}
\hline Parameter & $\begin{array}{c}\text { Initial stage of alloy } \\
{[\mathbf{n m}]}\end{array}$ & $\begin{array}{c}\text { Corroded stage of alloy } \\
\text { [nm] }\end{array}$ \\
\hline $\mathrm{R}_{\mathrm{p}, \mathrm{v}}$ & 191.536 & 1242.719 \\
\hline $\mathrm{R}_{\mathrm{q}}$ & 42.298 & 310.825 \\
\hline $\mathrm{R}_{\mathrm{a}}$ & 33.550 & 262.037 \\
\hline $\mathrm{R}_{\mathrm{z}}$ & 163.479 & 985.716 \\
\hline $\mathrm{R}_{\mathrm{s}, \mathrm{k}}$ & -0.944 & 0.286 \\
\hline $\mathrm{R}_{\mathrm{ku}}$ & 3.063 & 2.046 \\
\hline
\end{tabular}

\section{Conclusions}

The corrosion resistance of Ti-6Al-4V alloy in high temperature ionic liquid is significantly influenced by the microstructure of the alloy. High corrosion products were detected on macro-scale by XRD analyses in the present work, and the results revealed that $\mathrm{TiO}_{2}$ and $\alpha-\mathrm{Al}_{2} \mathrm{O}_{3}$ were the main products of the alloy in the high temperature ionic liquids. The corrosion rate indicates a very high speed of corrosion of the studied alloy in LiF-NaF-KF electrolyte at $823 \mathrm{~K}$, which means that Ti-6Al$4 \mathrm{~V}$ alloy is highly vulnerable to high temperature corrosion. This is the first study reported in the specialty literature on surface modification on Ti-6Al-4V alloy during corrosion in high temperature ionic liquids. SEM has shown that the corroded surface is not homogeneous and presents some points that can become corrosion centers. The corrosion occurs through the formation of a passive film and 
the corrosion products were identified by XPS as metal oxides. $\mathrm{TiO}_{2}$ was the main phase with small amount of $\mathrm{V}_{2} \mathrm{O}_{5}, \mathrm{Al}_{2} \mathrm{O}_{3}$ and $\mathrm{TiF}_{4}$. AFM images demonstrate the corrosion process by changing the shape but also give rise to roughness. We can conclude that this alloy is not recommended to be used at such a high temperature.

Acknowledgments: The work was financially supported by the Romanian Academy collaborative project/2012-2013 with Belarus Academy of Science. All support of the EU (ERDF) and Romanian Government that allowed for acquisition of the research infrastructure under POS-CCEO 2.2.1 project INFRANANOCHEM-Nr.19/01.03.2009, is gratefully acknowledged. The authors express their sincere thanks to Dr.P.Osiceanu for the fruitful discussions on XPS. Authors of the present paper have made equal contributions in conducting scientific researches and writing this paper.

\section{References}

1. BOYER, R., COLLINGS, E.W., WELSCH, G., Eds., Materials Properties Handbook: Titanium Alloys, ASM International, Ohio, 1993.

2. GURRAPPA, I., Characterization of titanium alloy Ti-6Al-4V for chemical, marine and industrial applications, Mater. Charact., 51 (2-3), 2003, 131-139.

3. RACK, H.J., QAZI, J.L, Titanium alloys for biomedical applications, Mat. Sci. Eng. C, 26, 2006, 1269-1277.

4. CVIJOVIC-AlAGIC, I., CVIJOVIC, Z., MitroviC, S., PANIC, V., RAKIN, M., Wear and corrosion behavior of Ti-13Nb-13Zr and Ti-6Al-4V alloys in simulated physiological solution, Corros. Sci., 53 (2), 2011, 796-808.

5. ELIAS, C.N., LIMA, J.H.C., VALIEV, R., MEYERS, M.A., Biomedical applications of titanium and its alloys, JOM, 60 (3) 2008, 46-49.

6. BLOYCE, A., QI, P.Y., DONG, H., BELL, T., Surface modification of titanium alloys for combined improvements in corrosion and wear resistance, Surf. Coat. Technol., 107, 1998, 125-132.

7. DONG, H., BELL, T., Enhanced wear resistance of titanium surfaces by a new thermal oxidation treatment, Wear, 238, 2000, 131-137.

8. REVANKAR, G.D., SHETTY, R., SRINIVAS, RAO, S., GAINTONDE, V.N, Wear resistance enhancement of titanium alloy (Ti-6Al-4V) by ball burnishing process, J. Mater. Res. Technol., 6 (1), 2017, 13-32.

9. ANUWAR, M., JAYAGANTHAN, R., TEWARI, V.K., ARIVAZHAGAN, N., A study on the hot corrosion of Ti-6Al-4V alloy, Mater. Lett., 61 (7), 2007, 1483-1488.

10 PESCHL, J., MALINOVSKY, M., Phase diagram of the system lithium fluoride-sodium chloridepotassium chloride, Chem. Zvesti, 32 (6), 1978, 755-759.

11. NEACSU, E.I., CONSTANTIN, V., SOARE, V., OSICEANU, P., POPA, M.V., Corrosion protection of steel using ZnNiP electroless coatings, Rev. Chim. (Bucharest), 64 (9), 2013, 994-999.

12. MOULDER, J.F., STICKLE, W.F., SOBOL, P.E., BOMBEN, K.D., Handbook of X-Ray Photoelectron Spectroscopy, CHASTAIN, J, KING, Jr. R.C., Eds., Physical Electronics, Inc., Eden Prairie, MN, USA, 1995.

13. GROSVENOR, A.P., BIESINGER, M.C., SMART, R.S.C., McINTYRE, N.S., New interpretations of XPS spectra of nickel metal and oxides, Surf. Sci., 600 (9), 2006, 1771-1779.

14. McCAFFERTY, E., Validation of corrosion rates measured by the Tafel extrapolation method, Coros. Sci., 47 (12), 2005, 3202-3215.

15. FACCHINI, L., MAGALINI, E., ROBOTTI, P., MOLINARI, A., Microstructure and mechanical properties of Ti-6Al-V produced by electron beam melting of pre-alloyed powders, Rapid Prototyping J., 15 (3), 2009, 171-178.

16. RAGHAVAN, V., J. Phase Equilib. Diff., Al-Ti-V (Aluminum-Titanium-Vanadium), 26 (3), 2005, 276-279.

17. POLMEAR, I., St JOHN, D., NIE, J.F., QIAN, M., Titanium Alloys in: Light Alloys 
Metallurgy of the Light Metals, 5th Ed., Butterworth-Heinemann, Oxford, 2017, 369-460.

18. KUMAR, S., SANKARA NARAYANAN, T.S.N., GANESH SUNDARA RAMAN, S., SESHADRI, S.K., Thermal oxidation of Ti6Al4V alloy: Microstructural and electrochemical characterization, Mater. Chem. Phys., 119 (1-2), 2010, 337-346.

19. International Centre for Difraction Data (JCPDS-ICDD), PCPDFWIN 1998, Ver. 2.00, cards No. 30-1429, 77-0332, 35-0486, 43-1154, 52-0859, 65-0428, 02-1121.

20. LEYENS, C., Oxidation and Protection of Titanium Alloys and Titanium Aluminides, in: Titanium and Titanium Alloys: Fundamentals and Applications, LEYENS, C., PETERS, M., Eds.,Wiley-VCH, Weinheim, Germany, 2003, 187-230.

21. LAUSMAA, J., J. Electron. Spectrosc. Relat. Phenom., Surface spectroscopic characterization of titanium implant materials, 81 (3), 1996, 343-361.

22. HERNANDEZ DE GATICA, N.L., JONES, G.L., GARDELLA, J.A., Surface characterization of titanium alloys sterilized for biomedical applications, Appl. Surf. Sci., 68 (1), 1993, 107-121.

23. SITTING, C., TEXTOR, M., SPENCER, N.D., WIELAND, M., VALLOTTON, P.H., Surface characterization, J. Mater. Sci. Mater. Med., 10, 1999, 35-46.

24. POUILLEAU, J., DEVILLIERS, D., GARRIDO, F., DURAND-VIDAL, S., MAHE, E., Structure and composition of passive titanium oxide films, Mat. Sci. Eng. B, 47 (3), 1997, 235-243.

25. KLIMOV, V.D., VASHMAN, A.A., PRONIN, I.S., Reaction of titanium atoms with a phosphorus trifluoride matrix at $77 \mathrm{~K}$. Cryochemical synthesis of a new compound: mono(trifluorophosphine) titanium(II) fluoride (TiF2.PF3), Zh. Obshch. Khim., 61, 1991, 2166-2174.

26. NEFEDOV, V.I., FIRSOV, M.N., SHAPLYGIN, I.S., Electronic structures of $\mathrm{MRhO}_{2}, \mathrm{MRh}_{2} \mathrm{O}_{4}$, $\mathrm{RhMO}_{4}$ and $\mathrm{Rh}_{2} \mathrm{MO}_{6}$ on the basis of X-ray spectroscopy and ESCA data, J. Electron Spectrosc. Relat. Phenom., 26 (1), 1982, 65-78.

27. HO, S.F., CONTARINI, S. RABALAIS, J. W., Ion-beam-induced chemical changes in the oxyanions (Moyn-) and oxides (Mox) where $\mathrm{M}=$ chromium, molybdenum, tungsten, vanadium, niobium and tantalum, J. Phys. Chem., 91 (18), 1987, 4779-4788.

28. BACOS, M.P., MOREL, A., NAVEOS, S., BACHELIER-LOCQ, A., JOSSO, P., THOMAS, M., The effect of long term exposure in oxidising and corroding environments on the tensile properties of two gamma-TiAl alloys, Intermetallics, 14 (1), 2006, 102-113.

29. THOMAS, M., BACOS, M.P., Processing and Characterization of TiAl-based Alloys

Towards an Industrial Scale, High. Temp. Mater., 3, 2011, 1-11.

30. GURRAPPA, I., GOGIA, A.K., High performance coatings for titanium alloys to protect against oxidation, Surf. Coat. Technol., 139 (2-3), 2001, 216-221.

$\overline{\text { Manuscript received: } 13.02 .2020}$ 